Kong. Res. J. 2(2) : 100-104, 2015

ISSN 2349-2694

Kongunadu Arts and Science College, Coimbatore.

\title{
COMPARISON OF VERMICOMPOST AND LEAF MOLD ON THE GROWTH AND YIELD OF CAPSICUM ANNUUM L.VAR. FRUTESCENS (L.) KUNTZE
}

\author{
Mary Kensa, $\mathbf{V}^{*}$. \\ PG and Research Centre, Department of Botany, S.T. Hindu College, Nagercoil. \\ *E.mail: surejkensa@gmail.com
}

\begin{abstract}
An experiment was conducted to determine the effect of vermicompost on the growth and yield ofCapsicum annuumvar. frutescens (Kantharimilagu). Vermicompost is a rich source of vitamins, enzymes, macro and micronutrients which when applied to plants help in efficient growth. The major thrust of this investigation was focused on the growth and yield of Capsicumannuumvar. frutescensusing the vermicompost prepared by the earthworm species namely Eudriluseugeniaeon the biodegradation of Banana waste (Musasps) mixed with cow dung 3:1. The present study has been carried out to evaluate thephysico-chemical characteristics, micronutrients and macronutrients, and also a comparative study was done on the effect of vermicompost on growth parameters namely root length, shoot length, number of leaf and number of flower and length of fruits in Capsicum annuumvar. frutescens. The results of the study revealed that the plants treated withvermicompostshowed $\mathrm{C} / \mathrm{N}$ ratio increasedin macronutrients $(\mathrm{N}, \mathrm{P}, \mathrm{K}, \mathrm{Ca}, \mathrm{Na}, \mathrm{Mg}$ and $\mathrm{C}$ ) and micronutrients $(\mathrm{Fe}, \mathrm{Cu}, \mathrm{Mg}$ and $\mathrm{Zn}$ ) than the plants grown in leaf mold and control.The vermicompost applied plant (Capsicum annuumvar. frutescens) showed increased root and shoot length, number of leaves, number of flowers and length of fruits than the plants which are not treated with vermicompost. Hence based on the various biochemical studies performed it is concluded that this quality of bio solid vermicompost obtained from the degradation of banana wastes by Eudriluseugeniae is an effective biofertilizer which would facilitate the increased uptake of the nutrients by the plants resulting in higher growth and yield.
\end{abstract}

Keywords: Biofertilizer, degradation, macro nutrients,vermicompost, yield.

\section{INTRODUCTION}

Vermicomposts are products derived from the accelerated biological degradation of organic wastes by earthworms and microorganisms. Earthworms consume and fragment the organic wastes into finer particles by passing them through a grinding gizzard and derive their nourishment from microorganisms that grow upon them. The process accelerates the rates of decomposition of the organic matter, which in turn alter the physical and chemical properties of the material, leading to a humification effect in which the unstable organic matter is fully oxidized and stabilized (Albanell et al., 1988; Orozco et al., 1996). The end product, commonly referred to as vermicompost is greatly humified through the fragmentation of the parent organic materials by earthworm sand colonization by microorganisms (Edwards, 1998). From earlier studies also it is evident that vermicompost provides all nutrients in readily available form and also enhances uptake of nutrients by plants. Sreenivas et al. (2000) studied the integrated effect of application of fertilizer and vermicompost on soil available Nitrozen $(\mathrm{N})$ in ridge gourd (Luffa acutangula). Similarly, the uptake of N, phosphorus $(\mathrm{P})$, potassium $(\mathrm{K})$ and magnesium $(\mathrm{Mg})$ was found to be higher in (Oryzasativa) plant when it was applied with vermicompost (Jadhav et al., 1997).

\section{MATERIALS AND METHODS}

The present work was carried during the year August 2013 - December 2013, at Marayapuram, Marthandam, K.K. Dist, and Tamil Nadu. To effectively recycle, the locally available banana waste, the earthworm species Eudriluseugeniaewas used. Culture of Eudriluseugeniaespecies of earthworms were set up using large baskets for the production vermicompost. The basal layer of the vermi-bed comprised of broken bricks followed by a layer of coarse sand in order to ensure proper drainage. A layer of loamy soil was placed at the top. 50 locally collected earthworms are introduced in tothe soil. Fresh cattle dung was scattered over the soil and then it was covered with a dried banana waste. Water was added to the unit in order to keep it moist. The plant waste along with cattle dung was over turned once a week. After 60 days, 
vermicompost units were regularized for the harvesting of vermicompost every 20 days.

Leaf mold compost was prepared by using loamy soil, leaf wastes and some dropping of animal waste in the ratio of 3:2:1. Enough water was added at regular intervals. After 30 days, leaf mold compost was ready.

After preparing the media (vermicompost, leaf mold compost) the seeds of Capsicumannuumfrutescensare sown on the ordinary soil and watered regularly. After 15 days, selected freshly grown nursery plants are planted in a medium of vermicompost and leaf mold compost separately. The seedlings are watered regularly. A control set up is maintained. The following growth parameters are recorded at harvest (after 15 weeks)

1) Root length

2) Shoot length

3) Number of leaves per plant

4) Number of flowers

5) Number of fruits and

6) Length of fruits
On 15 th week, the plants were taken out of the gunny bags and the above listed growth parameters were measured. The physico- chemical parameters such as macro and micro nutrients, $\mathrm{pH}$ and electrical conductivity (Jackson, 1973) are analysed.

\section{RESULTS AND DISCUSSION}

The physico-chemical properties of vermi compost, leaf mold compost and control are listed in Table 1. All the physico-chemical parameters except $\mathrm{pH}$ increased significantly in pots of vermicompost followed by leafmold compost and control. The content of micro nutrients like $\mathrm{Mn}-8 \mathrm{ppm}, 6 \mathrm{ppm}$ and 2.03 ppm; $\mathrm{Zn}-4.5 \mathrm{ppm}, 3.6 \mathrm{ppm}$ and $3.5 \mathrm{ppm}$; $\mathrm{Cu}$ - $1.5 \mathrm{ppm}, 1.2 \mathrm{ppm}$ and $0.045 \mathrm{ppm} ; \mathrm{Fe}-9.9$ ppm,9 ppm, 4.3 ppm; Mg 5.2 ppm, 4.1 ppm, 2.44 ppm; Ca-8.5 ppm, 6.2 ppm and 4.09 ppm; K-65\%, $55 \%$ and $45 \%$; P-8.25\%, 6.15\% and $0.03 \%$; $\mathrm{N}-2.2 \%$, $2.01 \%$ and $0.6 \%$; $\mathrm{C}-3.07 \%, 1.07 \%$ and $0.09 \%$ in Vermicompost, leaf mold compost and control respectively (Table 1). $\mathrm{pH}$ (7.5) decreased in vermicompost, followed by 7.7 in leaf mold compost and 7.9 in control. Like that electrical conductivity (EC) was 1.40 in vermicompost followed by 1.36 and 1.35 in leaf mold compost, control respectively.

Table 1. Physico-chemical properties of vermicompost and leaf mold compost.

\begin{tabular}{|c|c|c|c|c|c|c|c|c|c|c|c|c|}
\hline 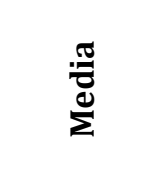 & 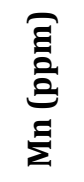 & 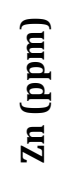 & 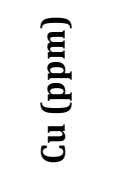 & 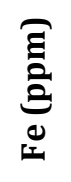 & 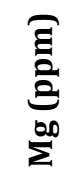 & 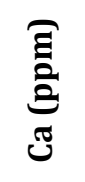 & $\checkmark \sqrt{e}$ & $\underbrace{\frac{a}{a}}_{a}$ & $\underbrace{a}_{z}$ & u & $\frac{\pi}{2}$ & 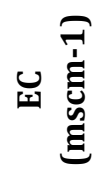 \\
\hline $\begin{array}{c}\text { Vermi } \\
\text { compost }\end{array}$ & 8 & 4.5 & 1.5 & 9.9 & 5.2 & 8.5 & 65 & 8.25 & 2.2 & 3.01 & 7.5 & 1.40 \\
\hline $\begin{array}{l}\text { Leaf mold } \\
\text { compost }\end{array}$ & 6 & 3.6 & 1.2 & 9 & 4.1 & 6.2 & 55 & 6.15 & 2.01 & 1.07 & 7.7 & 1.36 \\
\hline $\begin{array}{c}\text { Sterile } \\
\text { soil } \\
\text { (Control) } \\
\end{array}$ & 2.03 & 3.5 & 0.045 & 4.3 & 2.44 & 4.09 & 45 & 0.03 & 0.6 & 0.09 & 7.9 & 1.35 \\
\hline
\end{tabular}

Table 2. Effects ofvermicompost and leaf mold on the growth of Capsicum annuumL. var. frutescens (L.) Kuntze

\begin{tabular}{ccccccc}
\hline Media & $\begin{array}{c}\text { Root } \\
\text { Length } \\
\text { (cm) }\end{array}$ & $\begin{array}{c}\text { Shoot } \\
\text { length } \\
\text { (cm) }\end{array}$ & $\begin{array}{c}\text { Number of } \\
\text { flowers (cm) }\end{array}$ & $\begin{array}{c}\text { Number of } \\
\text { fruits (cm) }\end{array}$ & $\begin{array}{c}\text { Length of } \\
\text { fruits (cm) }\end{array}$ & $\begin{array}{c}\text { Number of } \\
\text { leaves }\end{array}$ \\
\hline $\begin{array}{c}\text { Vermicompost } \\
\text { Leaf Mold } \\
\text { compost }\end{array}$ & 7.5 & 16.5 & 15 & 13 & 2.2 & 10 \\
$\begin{array}{c}\text { Sterile Soil } \\
\text { (Control) }\end{array}$ & 5 & 13 & 11 & 6 & 2 & 6 \\
\hline
\end{tabular}


Effects of the application of various fertilizers on different morphological parameters such as root length, shoot length, number of leaves, number of flowers, number of fruits and length of fruits were determined after harvesting. All the morphological parameters increased significantly for the plants treated with vermicompost than with leaf mold compost and control. At the harvesting time, the plants treated with vermicompost, leaf mold and control showed the increase in length of roots $7.5 \mathrm{~cm}$, $9 \mathrm{~cm}$ and $5.5 \mathrm{~cm}$, shoot length increased $16.5 \mathrm{~cm}, 13$ $\mathrm{cm}$ and $11 \mathrm{~cm}$; number of flowers 15, 11 and 9; number of fruits 13, 6 and 3; length of fruits $2.2 \mathrm{~cm}, 2$ $\mathrm{cm}$ and $1.2 \mathrm{~cm}$ and number of leaves 10,6 and 5 respectively (Table 2 ).

The results of the decrease in the $\mathrm{pH}$ of soil treated with vermicompost when compared with control,the increased soil electrical conductivity and the increased soil nutrients (nitrogen, phosphorous, potassium, carbon, calcium, magnesium, manganese, copper, zinc and magnesium) are in agreement with the earlier work done by Ismail (2005); Lalitha et al., (2000); Azarmi et al., 2008). Similarly, the result of growth and yield of $C$. annuum with present study increased root length, shoot length, number of leaves, flowers, fruits and length of fruits is in accordance with Marinari et al. 2000); Erich et al. (2002); Gajalakshmi and Abbasi (2002); Arancon et al. (2004); Chamani et al. (2008);Hameeda et al. (2007); Zaller (2007); Rajbir. (2008).

The decrease in total nitrogen properties in soils without vermicompost is due to larger amount of carbon and nitrogen, in vermicompost and leaf mold compost that could have provided a larger source of nitrogen for mineralization (Arancon et al., 2006). There have been other reports of increase of nitrogen in soil after application of vermicompost (Nethra et al., 1999). In this experiment, the more available potassium probably could have contributed to decrease of soil $\mathrm{pH}$ caused from the application of vermicompost. The selective feeding of earthworm on originally rich substances which breakdown during passage through the gut, biological grinding, together with enzymatic influence of finer soil particles are likely to be responsible for increasing the different forms of potassium (Rao et al., 1996). Vermicompostprovides nutrients in more available forms to plants such as phosphates, exchangeable calcium and soluble potassium (Orozco et al., 1996).

Furthermore, the results showed that the available zinc concentration in soil was significantly affected by vermicompost treatments. The total zinc content, $\mathrm{pH}$, organic matter of the soil affects the zinc availability (Alloway, 1993). The soil pH is the most important factor controlling zinc availability, which decreases with the increase of the $\mathrm{pH}$. In this experiment increased zinc was attributed to the $\mathrm{pH}$ reduction and the greater organic matter degradation. The earlier findings of Atiyeh (2001) and Maheshwarpa et al. (1999) supported the present result of reduction of soil pHwith increase of vermicompost rate in the soil.

The soils amended with vermicompost had significantly higher electrical conductivity (EC) than the control. The soil EC increased with increasing the application rate of vermicompost in soil as reported by Atiyeh et al. (2001). The EC of vermicompost depends on the raw materials used for vermicomposting and their ion concentration (Atiyeh, 2002b). The manganese availability in the soil was significantly affected by vermicompost treatments. Also the results revealed that the soil copper concentration did not differ significantly between the treatments.

Length of root, stem, number of leaves, flowers and fruits are maximum in plants treated with vermicompost followed by leaf mold compost and control (Table 2). The maximum number of leaves observed with in vermicompost treated plants can be accounted for by the fact that vermicompost are high in nitrogen which is responsible for rapid plant growth. The plant height observed after harvest was maximum for in vermicompost and leaf mold compost treated plants followed by control. The yield of the fruit per plant in vermicompost treatment was maximum followed by leaf mold compost and control. The increased plant growth in vermicompost than leaf mold compost and control may be due to the impact of microbes in biofertilizers (Lalitha et al., 2000; Ansari, 2008 a).

Vermicompost and leaf mold compost are also enriched with certain metabolites and vitamins which enhance the plant growth (Lalitha et al., 2000; Ansari, 2008 a; b). According to Lalitha et al., (2000), application of vermicompost and leaf mold compost has an emphatic effect on plant growth and production. The higher yield due to application of vermicompost may be attributed to the higher level of nutrients along with growth stimulating substances exerted by earthworms into their casts. Tomati et al. (1988) clearly stated the influence of microbial, hormones like substances on the plant metabolism, growth and development by vermicompost. The result of the present study goes in agreement with the findings of Aruna and 
NassaReoldy (1999) in Soyabean and in Capsicumsps.

Nazari et al. (2008) reported that the application of compost media is an integral element for improving growth, flowering and development of plants. Application of vermicompost in soil increases enzyme activities such as urease, phosphomonoesterase, phosphodiesterase and arylsulphatase (Albiach et al., 2000). Plant growth promoting bacteria directly stimulate the growth by nitrogen fixation, solubilisation of nutrients, antagonizing pathogenic fungi by production of siderophores, chitinase, B-1-3-glucanase, antibiotics and cyanide (Han et al., 2005).

The present study showed a remarkableincrease in root and shoot length in plantstreated with vermicompost. Similar result was reported by Packiaraj and Venkataraman (1991) who found that the addition of coir waste increased the height of rice plants and Liyanage et al. (2005) found that the application of coir dust and coconut husk to coconut resulted in greater number and weight of roots.

Hence the present study clearly indicated that the application of vermicompost and leaf moldcompost had a significant influence on various morphological parameters. Addition of vermicompost to soil increased nutrient content in the substrate and gave higher concentrations of $\mathrm{P}$, $\mathrm{Ca}, \mathrm{Mg}, \mathrm{Cu}, \mathrm{Mn}$ and $\mathrm{Zn}$ in shoot tissues of red clover and cucumber (Sainz et al., 1998). Further, Kumari and UshaKumari, 2002 reported that enriched vermicompost was a better treatment for enhancing the uptake of $\mathrm{N}, \mathrm{P}, \mathrm{K}, \mathrm{Ca}$ and $\mathrm{Mg}$ by Cowpea. Thus nutrient uptake enhancement aided through vermicompost, increase the growth of plants. Vermicompost are comprised of large amount of humic substances some of the effects of which on plant growth are similar to those of soil-applied plant growth regulators (Muscolo et al., 1999). Aracnon et al., (2006) reported that enhanced availability of plant growth influencing substances produced by microorganisms in vermicompost were factors considered to have contributed to increased fruit yield in peppers. These findings support our observations that vermicompost significantly enhanced the growth of the plants and also increases the microbial diversity of vermicompost applied soil.

\section{REFERENCES}

Albanell, E., J. Plaixats and T. Cabrero, (1988). Chemical changes during vermicomposting (Eiseniafetida) of sheep manure mixed with cotton industrial wastes. Biol. Fertil. Soils $\mathbf{6}$ : 266-269.

Albiach, R., R. Canet, F. Pomares and F. AndIngelmo, (2000). Microbial biomass content and enzymatic activities after application of organic amendments to a horticultural soil. Bioresour. Technol. 75: 43-48.

Alloway, B. (1993). Heavy metal in soils, Black Academic, New York, p. 339.

Ansari, A.A. (2008a). Effect of vermi compost on the productivity of potato (Solanumtuberosum), Spinach (Spinach oleracea) and Turnip (Brassica campestris). World J. Agric. Sci. 4(3): 333-336.

Arancon, M., A. Manico, and G. Verago, (2004). Influences of vermicomposts on field strawberries: 1. Effect on growth and yields. Bioresour. Technol. 93: 831-840.

Arancon, N.Q., C.I. Edwards and P. Bierman, (2006). Influences of vermicomposts on field strawberries. Effects on soil microbiological and chemical properties. Bioresour. Technol. 97: 831-840.

Aruna, V. and N. Nasa, (1999). Response of Soybean (Glycine Max L.) to conjunctive use of organic and inorganic sources of nitrogen. Ind. J. Agric. Sci. 69(5): 382-383.

Atiyeh, M. (2001). Pig manure vermicompost as a component of a horticulture bedding plant medium. Effects on physiochemical propertie and plant growth bioresour. Technol. 78: 11-20.

Atiyeh, M. (2002b). The influences of humic acids derived from earth worm-processed organic wastes on plant growth. Bioresour. Technol. 84:7-14.

Azarmi, R., P. Sharifi, and M.R. Satari, (2008). Effect of vermicompost on growth, yield and nutrition status of tomato (Lycopersicumesculentum) In press.

Chamani, E., D.C. Joyce, and A. Reihanytabar, (2008).Vermicompost effects on the growth and flowering of Petunia hybrida 'Dream Neem Rose'. Am. Eruas. J. Agric. Environ. Sci. 3(3): 506512.

Edwards, C.A. (1998). The use of earthworms in the breakdown and management of organic wastes. In: Earthworm Ecology. CRC press LLC, Boca Raton, Fl, 327-354. 
Erich, M.S., C.B. Fitzgerald and G. Porter, (2002). The effect of organic amendments on phosphours chemistry in a potato cropping system. Agr. Ecosyst. Environ. 88: 79-88.

Gajalakshmi, S. and S.A. Abbasi, (2002).Effect of the application of water hyacinth. Bioresour. Technol. 23: 7-14.

Hameeda, B.G., O.P. Harini, Rupela and G. Reddy, (2007). Effect of composts on Sorghum growth and mycorrhizal colonization. Afr. J. Biotechnol. 6: 9-12.

Han, J., L. Sun, X. Dong, Z. Cai, H. Yang, Y. Wang and W. Song, (2005). Characterization of a novel plant growth-promoting bacteria strain Delftiatsuru hatensis HR4 both as a diazotroph and a potential biocontrol agent against various pathogens. Syst. Appl. Microbiol. 28: 66-76.

Ismail, S.A. (2005). The earthworm Book other India Press, Mapusa Goa, 92.

Jackson, M.L. (1973). Soil chemical analysis, Prentice HallIndia Pvt Ltd, New Delhi, India, 498-516.

Jadhav, K. (1997). Influence ofthe conjunctive use of FYM, Vermicompost and urea on growth and nutrient uptake in rice. J. Maharash. Agric. Unvi. 22(2): 249-250.

Kumari, M.S. and K. Ushakumari, (2002). Effect of vermicompost enriched with rock phosphate on the yield and uptake of nutrients in cowpea (Vignaun guinculata L. walp). J. Trop. Agric. 40: $27-30$.

Lalitha, A., B. Foscola and G. Rupa, (2000).The impact of biopesticide and microbial fertilizers on productivity and growth of Abelmoschuse sculentus. Vaundara. Earth 1-2: 4-9.

Liyanage, R., T.C. Martingo and D. Myrugan, (2005). Vermicompsoting of cattle and goat manures by Eisenia foetida and their growth and reproduction performance. Biores. Technol. 96: 111-114.

Maheswarappa, H.P., H.V. Nanjappa and M.R. Hegde, (1999). Influence of organic manures on yield of arrowroot, soil physico-chemical and biological properties when grown as intercrop in coconut garden. Ann. Agric. Res. 20(3): 318323.

Marinari, S., G. Masciandaro, B. Ceccanti and S. Grego, (2000). Influence of organic and mineral fertilizers on soil biological and physical properties. Bioresour. Technol. 72: 9-17.

Muscolo, A., Holler, E. Sokala and U. Tollera, (1999). Earth worm humic matter produces auxin-like effects on Dacuscarotacell growth and nitrate metabolism. Soil Boil. Biochem. 31: 1303-1311.

Nazari, K., Sollare and G. Aridi, (2008). The effect of different soil amendment on growth and flowering of African Marigold (Tageteserecta L.) Queen J. Fruit Ornamental Pl. Res. 16: 403-415.

Nethra, N.N., K.V. Jayaprasad and R.D. Kale, (1999). China aster [Callistephus chinensis(L)] cultivation using vermicompost as organic amendment. Crop Res. Hisar 17(2): 209-215.

Orozco, F.H., J. Cegarra, L.M. Trujillo and A. Roig, (1996). Vermicomposting of coffee pulp using the earthworm Eiseniafetida: effects on $\mathrm{C}$ and $\mathrm{N}$ contents and the availability of nutrients. Biol. Fert. Soils 22: 162-166.

Rajbir, U. (2008). Vermicompost substitution influences growth, physiological disorders, fruit yield and quality of straw berry (Fragaria xananassa Duch). Bioresour. Technol. 17: 85078511.

Rao, S., A. Subba Rao and P.N. Takkar, (1996). Changes in different forms of K.Under earthworm activity. National Seminar on organic Farming and sustainable Agriculture, India, 9-11.

Sreenivas, C., S. Muralidhar and M.S. Rao (2000).Vermicompost, a viable component of IPNSS in nitrogen nutrition of ridge gourd. Ann. Agric. Res. 21(1): 108-113.

Tomati, U.A., Grappelli and E. Galli, (1988). The hormone -like effect of earthworm casts on plant growth. Biol. Fertil. Soils.5: 288-294.

Zaller, J.G. (2007). Vermicompost as a substitutefor peat in potting media: Effects on germination, biomass allocation, yields and fruit quality of three tomato varieties. Sci. Hortic. 4: 122-199. 